\title{
The Impact of Women Parliamentarians on Economic Growth: Modelling \& Statistical Analysis of Empirical Global Data
}

\author{
Eman Khorsheed \\ Correspondence: Department of Mathematics, College of Science, University of Bahrain, P.O. Box 32038, Sakhir, \\ Kingdom of Bahrain. E-mail: ekhorsheed@uob.edu.bh
}

Received: January 29, 2020

Accepted: March 31, 2020 Online Published: April 9, 2020

doi:10.5539/ijsp.v9n3p23

URL: https://doi.org/10.5539/ijsp.v9n3p23

\begin{abstract}
The impact of empowering women on economic growth is investigated through testing the influence of proportion of women candidates in parliaments. To obtain a long-term view, cross-country analysis is performed in parallel using 10 years World Bank data of 72 countries divided into the UN income-groups: 1-high, 2-upper-middle, 3-lower-middle, and 4- low-income. Statistical analysis reveals severe degree of multicollinearity. To unveil the desired connection, two approaches are implemented. Principle Component Regression is used to assess the independent impact of women parliamentarians. The results demonstrate a positive significant influence: $10 \%$ increase in female parliamentarians increase growth by $0.27 \%, 0.36 \%, 0.22 \%$, and $0.49 \%$, respectively. To unveil the joint influence of the considered indicators, interaction regression models are developed. The method demonstrates superior results. This work provides an empirical evidence on the positive impact of women political empowerment with respect to stimulating a sustainable economic growth.
\end{abstract}

Keywords: sustainable economic growth, statistical modelling, regression analysis, panel data, machine learning techniques, women empowerment

\section{Introduction}

Growth has always been considered as one of the main economic goals (McConnell, Brue, \& Flynn, 2002). Hence, as a goal, an economy that can achieve growth will be able to produce market value of goods and services that meet the individual needs and resolve socio-economic problems.

Several economists developed theories and models of economic growth. For example, Solow and SWAN (1956) built an exogenous model that links economic growth with population growth, saving rates, capital accumulation, and technological progress. However, the model lacks the ability to explain how in the long-term growth is achieved. Recently, endogenous models consider the accumulation of human capital as the main engine of growth, which the first is due to Lucas (1988). In this latter model, the inputs are investments in human capital or in information spillover from accumulation of physical capital, which in the existence of technological progress reveals greater output (Barro, 1996). Moreover, the study conducted by Lucas (1988) emphasizes the role of education and time allocated between work and skills acquisition on generating economic growth. Barro (1991) concluded that per capita growth rate is positively linked with the level of human capital. A growing body of empirical evidence suggests that gender inequality, for example, in education can impede economic growth (Hill \& King, 1995; Klasen, 2002; Knowles et al., 2002; Klasen \& Lamanna, 2009), and that economies with more highly educated leaders tend to grow faster (Besley et al., 2011). In addition, gender gaps in economic participation can result in huge GDP losses across nations of all income levels as reported by Elborgh-Woytek et al. (2013) and Stotsky (2006).

United Nations (UN) women report (2005) highlighted the positive role of women economic empowerment on nation's economic growth. Furthermore, women's participation in all areas of public life is emphasized to be essential for the full development of economic, cultural, political and social reform programs. Female's participation is no longer considered a form of social luxury, but a dire need imposed by the global competition, see for example, (Bhoganadam, Malini, \& Rao, 2014) and (Blackden et al., 2007).

Many researchers reveal the positive impact of women participation in labor markets on economic growth; see for example (Klasen, 2004; Dollar \& Gatti, 1999). Few others, such as Dollar et al. (2001) shed light on the role of female parliamentary representation on corruption reduction. On the other hand, industrial revolution and socio-economic modernization are, in general, recognized to increase the proportion of seats women held in national parliaments. However, women political contribution to economic growth has been rarely explored and therefore very few studies 
exist in the literature, one of which is that of Jayasuriya and Burke (2013). The latter authors' method is based on using both the fixed-effects estimator and the system Generalized Method of Moments (GMM) estimator. Their results provide evidence that women participation in political life is important toward economic development.

Most of the available literature focus on only high-income economies. Khorsheed (2019), for example, studied the impact of proportions of seats held by women in parliaments on the growth of 20 high-income countries excluding USA. This research extends the work of Khorsheed (2019) by investigating the relationship between women parliamentarian and economic growth of all four UN income categories: high (including USA \& Netherland), upper-middle, lower-middle, and low income. The analysis is administered using regression approaches and machine learning by the aid of the statistical software R.

\section{Panel Data}

Economic growth on the long term differs among countries. In the past, the diversity is due to a lack or wealth of natural resources such as fertile agricultural soils and deposits of oil \& gas in countries' territories. Nowadays, all types of nation resources- natural capital, physical capital, and human capital are widely recognized as main indicator of economic development. A statistical universal metrics that is easy to calculate and provide a good estimate of the relative productivity of any nation is the gross domestic product (GDP) per capita. Depending on the gross national income (GNI) which includes GDP, the World Bank divided economies into four income groups: high, upper-middle, lower-middle, and low.

Education and health are the key dimensions of human capital that contribute to economic growth. Unlike most high-income countries, low-income nations suffer from unstable economic growth with greater proportions of uneducated and unhealthy populations. In the human capital growth model of Locas (1988), for example, the variety in the growth rate was found to be affected by the nation's level of political stability and functioning of institutions. In this study, the main aim is to investigate the impact of women proportion of seats in national parliaments on economic growth. To account for other major determinants of growth and the potential effects of any possible interactions between these indicators, the following variables are also considered: population growth, initial Gross Domestic Product (GDP) per capita (constant 2006), \& Foreign Direct Investment (FDI).

Taking into consideration the special features of each income category, panel data for these groups are aggregated from the World Bank database for the period 2006-2015. From the high-income economies, 22 countries are considered including USA and Netherland. From the upper-middle and lower-middle income groups 20 and 13 countries are involved including China and Liberia, respectively. Seventeen low-income countries are also considered. This group contains The Haiti and Nepal beside 15 African nations including Rwanda. The full list of countries included in this study categorized according to level of income are displayed in Table 1.

Table 1. List of countries included in this study categorized according to level of income

\begin{tabular}{|l|l|l|l|}
\hline \multicolumn{2}{|c|}{ UNCOME GROUP } \\
\hline High & \multicolumn{1}{|c|}{ Lower-Middle } & \multicolumn{1}{c|}{ Low } \\
\hline Bahrain & Albania & Bolivia & Uganda \\
\hline Australia & Brazil & Cameron & Benin \\
\hline Kuwait & Bulgaria & Egypt & Burundi \\
\hline Oman & Bosnia \& Herzegovina & Honduras & Burkina Faso \\
\hline UAE & China & Kenya & Chad \\
\hline Austria & Colombia & Morocco & Ethiopia \\
\hline Belgium & Ecuador & Pakistan & Guiana \\
\hline Finland & Fiji & Philippine & Gambia \\
\hline France & Iraq & Sudan & The Haiti \\
\hline Germany & Kazakhstan & Uzbekistan & Liberia \\
\hline Greece & Mexico & Bangladesh & Madagascar \\
\hline Italy & Paraguay & India & Malawi \\
\hline Spain & Serbia & Tunisia & Nepal \\
\hline Sweden & Peru & & Niger \\
\hline UK & Romania & & Rwanda \\
\hline Denmark & Russian Federation & & Senegal \\
\hline Norway & Malaysia & & Zimbabwe \\
\hline Portugal & Venezuela & & \\
\hline Switzerland & Dominican & & \\
\hline Slovenia & South Africa & & \\
\hline USA & & & \\
\hline Netherland & & \\
\hline
\end{tabular}

Nations witness different proportions of seats taken by their women parliamentarians regardless of level of income. For 
example, although Rwanda categorized in the low-income group, it has been on the top of the 2017 UN list of countries with the most women parliamentarians over the whole decade $(61.3 \%)$. This is mainly because of the country's legally set quotas, with the Constitution stipulating that at least $30 \%$ of the national parliament seats must be for women. On the other hand, the Middle-East countries in the high-income category reveal the lowest women parliamentarians ratio among the group. These differences are due to several factors related to the state's customs and social traditions, religion, cultural, and political orientation.

The data consists of averages of ten years' development indicator time-series observations starting from year 2006. Table 2 displays the mean and standard deviation of every explanatory variable for each economy type. This table reveals that the highest averaged proportion of women parliamentarians is associated with the high-income group. The middle-income groups exhibit the largest mean economic growth that slightly exceeds 3.0. In addition, China, which is categorized within this group, has the largest GDP annual growth rate averaged $9.05 \%$ followed by Ethiopia. Although Ethiopia is a low-income country, it is among the fastest growing oil-free economies in the world after the government reforms that raised share of women political participation and opened the economy for foreign direct investments. On the other hand, the average GDP growth rate associated with the high-income economies is dominated by the recession experienced by some countries in this category. These countries are Kuwait, Oman, UAE, Greece, Italy and Spain. The recessions are expressed as negative growth rates in the dataset. Unexpectedly, the low-income group has the largest average FDI dominated by Liberia's average FDI that exceeded $40 \%$ during the considered period. The low-income group has also the highest population growth percentages.

\section{Methodology}

At the first stage of exploring the relationship between economic growth and the adopted development factors, a linear regression model is fitted for each income-group displayed in Table 1. The main variable of women parliamentarians' proportion appears significant at level of 0.1 only in the low-income model with no other significant terms. The corresponding coefficient of determination is reasonable $\left(R^{2}=0.4\right)$. Other than this exception, the linear fits turned most explanatory variables insignificant in all developed models. This unveils the presence of the multicollinearity phenomenon detected from the 2D scatter plots of pairwise relations between the variables as demonstrated in Figure 1, and from the calculated significant correlations between different pairs of the considered variables. For example, the correlation between the proportion of female parliamentarians and population growth percentage within the high-income category is about -0.66 .

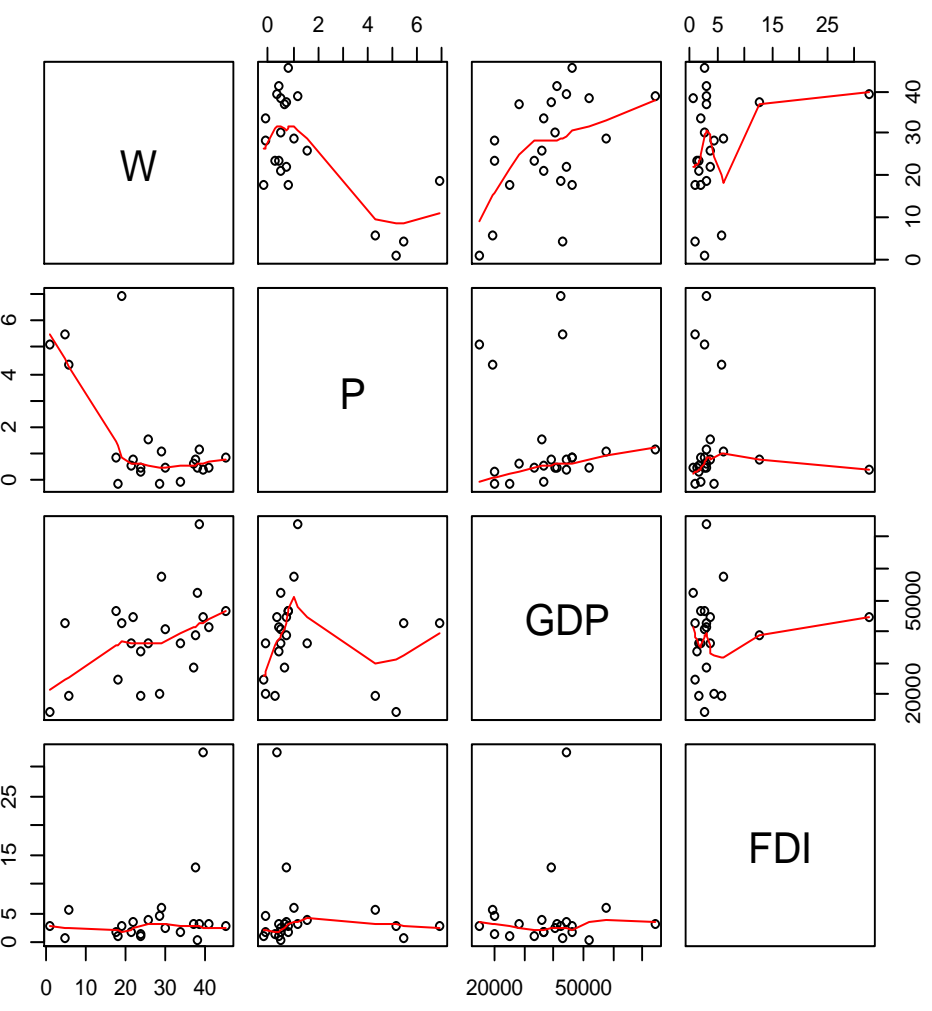

Figure 1. Two-dimension scatter plots of women parliamentarians' proportion (W), population growth percentage (P), GDP per capita, and foreign direct investment (FDI) within the high-income group 
To investigate the effect of women proportion in national parliaments on growth in the presence of the other acknowledged development indicators, Principle Components Analysis (PCA) and multiple interaction regression analysis are performed for each income group independently. Both analysis types are technically proceeded using the powerful approaches of machine learning by the aid of the statistical software R. Two models for each income group are developed using the available panel data and will be discussed next.

\section{Principal Component Regression Models}

When multicollinearity exists between predictors, regression coefficients can be estimated but probably with inflated standard errors, see for example Wheeler (2007). Such errors can result in inaccurate conclusions of tests of significance, which means that truly influential predictors may be considered insignificant (Dormann et al., 2012).

One way to overcome the multicollinearity problem revealed in the initial analysis of the cross-country data is to use orthogonal transformation to convert the set of correlated variables into another set of values of linearly uncorrelated variables called principle components (PCs).

Table 2. Data Descriptive Statistics: mean and standard deviation in ( )

\begin{tabular}{|l|c|c|c|c|}
\hline Indicator & High & $\begin{array}{c}\text { Upper- } \\
\text { Middle }\end{array}$ & $\begin{array}{c}\text { Lower- } \\
\text { Middle }\end{array}$ & Low \\
\hline Women seats in parliament \% & 26.4 & 20 & 18.5 & 20.6 \\
& $(12.4)$ & $(8.1)$ & $(7)$ & $(12.9)$ \\
\hline Population growth \% & 1.5 & 0.83 & 1.8 & 2.7 \\
& $(2.0)$ & $(1.0)$ & $(0.5)$ & $(0.7)$ \\
\hline Initial GDP/Capita (US\$) & 38168 & 4549 & 1268 & 420 \\
& $(13849)$ & $(1799)$ & $(774)$ & $(209)$ \\
\hline FDI \% & 4.5 & 4.2 & 2.6 & 5.5 \\
& $(6.8)$ & $(2.9)$ & $(1.4)$ & $(9.4)$ \\
\hline
\end{tabular}

The procedure for finding these components is known as the Principle Component Analysis (PCA). It is a powerful technique that has been widely used for dimensionality reduction. For more details on PCA, see Dillon et al. (1984).

Principal Component Regression (PCR), which is a type of regression analysis that uses the PCs to regress the dependent variable, can then be used to estimate the unknown regression coefficients in the standard linear regression model by only considering the significant PCs.

Let $c$ denotes country, $y_{c}$ be the corresponding average GDP/capita growth rate(\%), $p_{c}$ the average population growth percentage, $g_{c}$ the initial GDP/capita (2006), $w_{c}$ the average proportion of seats of women parliamentarians, and $f_{c}$ the foreign direct investment inflow percentage of GDP. To make the observations directly comparable they are all standardized so that each variable has a unit variance. Using the technique of Principal Component Analysis (PCA), four orthogonal principle components (PCs) are derived for each income group. The output of this analysis is displayed in Tables (3-6). Furthermore, regression linear models are fitted for the new set of uncorrelated variables. The associated coefficient of determination $R^{2}$ are approximately $0.4,0.4,0.6$, and 0.4 , respectively. This process rendered some PCs insignificant in each case as summarized in Table 7. A communality gives a measure of the amount of variance in each variable that is accounted for. It has 1 as an initial estimate since this is the total variance across all 4 components. The final communalities after extraction are presented in Table 8.

By eliminating the insignificant PCs and re-parameterizing the significant regression estimates back to the original variable space, the following Principle Components Regression (PCR) models are produced:

PCR model for High-Income group

$$
\hat{y}_{c}=0.018+0.027 w_{c}-0.244 p_{c}-\left(9.851 \times 10^{-6}\right) g_{c}+0.0235 f_{c}
$$

where $c=1, \ldots, 22$.

PCR model for Upper-Middle Income group

$$
\hat{y}_{c}=3.096+0.036 w_{c}+0.091 p_{c}-\left(3.896 \times 10^{-4}\right) g_{c}+0.0386 f_{c}
$$

where $c=1, \ldots, 20$. 
Table 3. Principle Component Analysis of High-Income group

\begin{tabular}{lllll}
\hline & PC1 & PC2 & PC3 & PC4 \\
\hline Women parliamentarian & 0.663 & -0.091 & 0.040 & -0.741 \\
\hline Population growth \% & -0.534 & 0.284 & -0.580 & -0.546 \\
\hline Initial GDP/capita & 0.430 & -0.157 & -0.813 & 0.361 \\
\hline Foreign Direct Investment & 0.302 & 0.941 & 0.044 & 0.148 \\
\hline PC standard deviation & 1.406 & 0.959 & 0.941 & 0.470 \\
\hline$\%$ of Variance & 49.38 & 22.98 & 22.12 & 5.523 \\
\hline
\end{tabular}

Table 4. Principle Component Analysis of Upper-Middle Income group

\begin{tabular}{lllll}
\hline & PC1 & PC2 & PC3 & PC4 \\
\hline Women parliamentarian & 0.412 & -0.375 & 0.829 & -0.049 \\
\hline Population growth \% & 0.634 & -0.118 & -0.328 & 0.691 \\
\hline Initial GDP/capita & 0.152 & 0.908 & 0.346 & 0.180 \\
\hline Foreign Direct Investment & -0.637 & -0.144 & 0.292 & 0.699 \\
\hline PC standard deviation & 1.298 & 1.014 & 0.909 & 0.679 \\
\hline$\%$ of Variance & 42.1 & 25.68 & 20.69 & 11.53 \\
\hline
\end{tabular}

Table 5. Principle Component Analysis of Lower-Middle Income group

\begin{tabular}{lllll}
\hline & PC1 & PC2 & PC3 & PC4 \\
\hline Women parliamentarian & -0.381 & 0.569 & -0.719 & 0.116 \\
\hline Population growth \% & 0.486 & -0.395 & -0.642 & -0.443 \\
\hline Initial GDP/capita & -0.635 & -0.125 & 0.116 & -0.754 \\
\hline Foreign Direct Investment & -0.464 & -0.711 & -0.239 & 0.472 \\
\hline PC standard deviation & 1.353 & 0.961 & 0.911 & 0.646 \\
\hline$\%$ of Variance & 45.75 & 23.07 & 20.76 & 10.42 \\
\hline
\end{tabular}

Table 6. Principle Component Analysis of Low-Income group

\begin{tabular}{lllll}
\hline & PC1 & PC2 & PC3 & PC4 \\
\hline Women parliamentarian & -0.389 & 0.639 & -0.481 & 0.458 \\
\hline Population growth \% & 0.572 & 0.067 & -0.728 & -0.373 \\
\hline Initial GDP/capita & -0.213 & -0.763 & -0.449 & 0.413 \\
\hline Foreign Direct Investment & 0.691 & 0.069 & 0.194 & 0.694 \\
\hline PC standard deviation & 1.199 & 1.070 & 0.917 & 0.761 \\
\hline$\%$ of Variance & 35.92 & 28.62 & 21.0 & 14.45 \\
\hline
\end{tabular}

Table 7. Significant principle component(s) obtained by PCR for each UN income group

\begin{tabular}{ccccc}
\hline & $P C 1$ & $P C 2$ & $P C 3$ & $P C 4$ \\
\hline High & $\times$ & & $\times$ & \\
\hline Upper-Middle & & $\times$ & & $\times$ \\
\hline Lower-Middle & & & & \\
\hline Low & & $\times$ & \\
\hline
\end{tabular}


Table 8. The initial and extraction communalities

\begin{tabular}{lccccc}
\hline & Initial & High & Upper-Middle & Lower-Middle & Low \\
\hline Women parliamentarian & 1 & 0.441 & 0.141 & 0.014 & 0.408 \\
\hline Population growth \% & 1 & 0.621 & 0.014 & 0.195 & 0.005 \\
\hline Initial GDP/capita & 1 & 0.845 & 0.825 & 0.569 & 0.582 \\
\hline Foreign Direct Investment & 1 & 0.093 & 0.020 & 0.222 & 0.005 \\
\hline
\end{tabular}

PCR model for Lower-Middle Income group

$$
\hat{y}_{c}=3.391+0.022 w_{c}-1.102 p_{c}-\left(1.271 \times 10^{-3}\right) g_{c}+0.439 f_{c}
$$

where $c=1, \ldots, 13$.

PCR model for Low Income group

$$
\hat{y}_{c}=2.229+0.049 w_{c}+0.095 p_{c}-\left(3.613 \times 10^{-3}\right) g_{c}+0.0072 f_{c}
$$

where $c=1, \ldots, 17$.

\section{Principle Component Regression Results}

The results of the PCR approach presented in models (1)-(4) reveal that all considered factors are significant at level 0.1 or lower. The key variable, seats held by women in parliament, which reflects the extent of female political empowerment, demonstrates a significant positive impact on economic growth regardless of nation's income level. Moreover, the effect of women political participation appears slightly greater on the group of low-income countries, which witnessed a relatively high female parliamentarians' proportion that exceeded 20, and economic growth of 2.23 , on average, in the last century. Based on this approach, a $10 \%$ increase in the proportion of seats held by women parliamentarians of income groups $1-4$ results, on average, in an increase of approximately $0.27 \%, 0.36 \%, 0.22 \%$, and $0.49 \%$ in economic growth, respectively.

Scientists have different views on the impact of population growth rates on GDP growth. Kelley and McGreevey (1994) found, in their historical study on developing countries, that high population growth rates have little effect on GDP growth. In economics, labor is considered an important factor of production and with an increase in the labor force by moderate population growth the nation's GDP may increase. Simon $(1981,1989)$ conducted two studies that harmonizes with this view. This author suggested that, in the long-run, population growth may have a positive impact on GDP through enhancing productivity by contributing new ideas and learning-by-doing. This may explain the positive impact of population growth on some nations such as China, which is now considered the second fastest economy in the world after USA. As models (2) and (4) reveal, the population growth of the upper-middle and the low-income nations may have a positive and almost equal effect on per capita GDP growth. Here, a $1 \%$ point increase in annual population growth may, on average, increase economic growth by approximately $0.1 \%$. These results are supported by the general growth theories and studies discussed above.

On the contrary, Birdsall \& Sinding (2001), Carlin (2006), and Headey \& Hodge (2009) claim that rapid population growth may have a significant negative effect on economic growth. In this research, the impact of annual population growth on economic GDP growth is negatively significant on both high and lower-middle economies with a stronger effect on the latter, where a $1 \%$ point increase in population growth is expected to lead, on average, to a decrease of $1.1 \%$ points in GDP growth rate.

The negative effect of the initial level of GDP/capita for 2006 although small, appears significant in all four models. This result may support the theory of conditional convergence discussed in Barro (1996).

Foreign Direct Investment has been widely acknowledged as an economic growth-enhancing factor. This is because FDIs may deliver technological advances, increase the exporting capability of the host country, and lead to profit increase at a foreign exchange. Therefore, it is considered as one of the most famous sorts of investment in the world especially in developing countries. For some related studies, the reader is referred to (Younus et al., 2014; Dritsaki \& Stiakakis, 2014; Falki, 2009; Saqib et al., 2013) and the references therein.

As expected, the foreign direct investment contributes positively and significantly to GDP growth in all income-based developed models. The strongest impact of this factor is associated with the lower-middle income cross-section, where a $1 \%$ increase in FDI is expected, on average, to increase growth rate by approximately $0.44 \%$. The corresponding expected increment in the upper-middle, high and low-income nations' growth rates are $0.039 \%, 0.024 \%$, and 0.007 , 
respectively. These results match the existing empirical literature; see for example, Grossman \& Helpman (1991) and Hermes \& Lensink (2003).

The results of this approach and the associated diagnostic plots are displayed in Figure 2 and Figure 3 . These results reveal a reasonable fit of the 72 nations' panel data and are discussed further in the last section.

High-Income

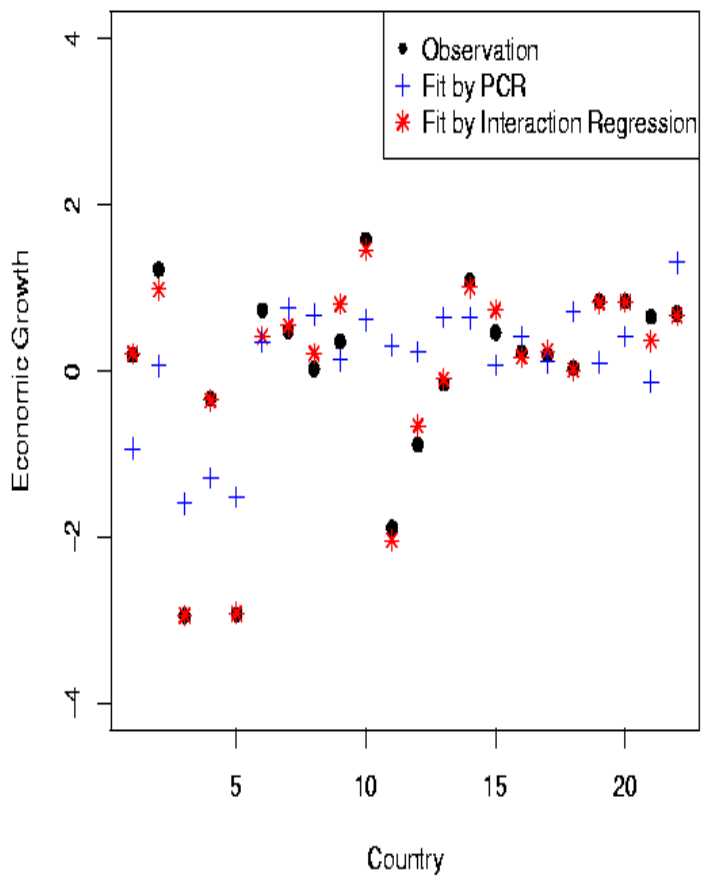

Lower-Middle-Income

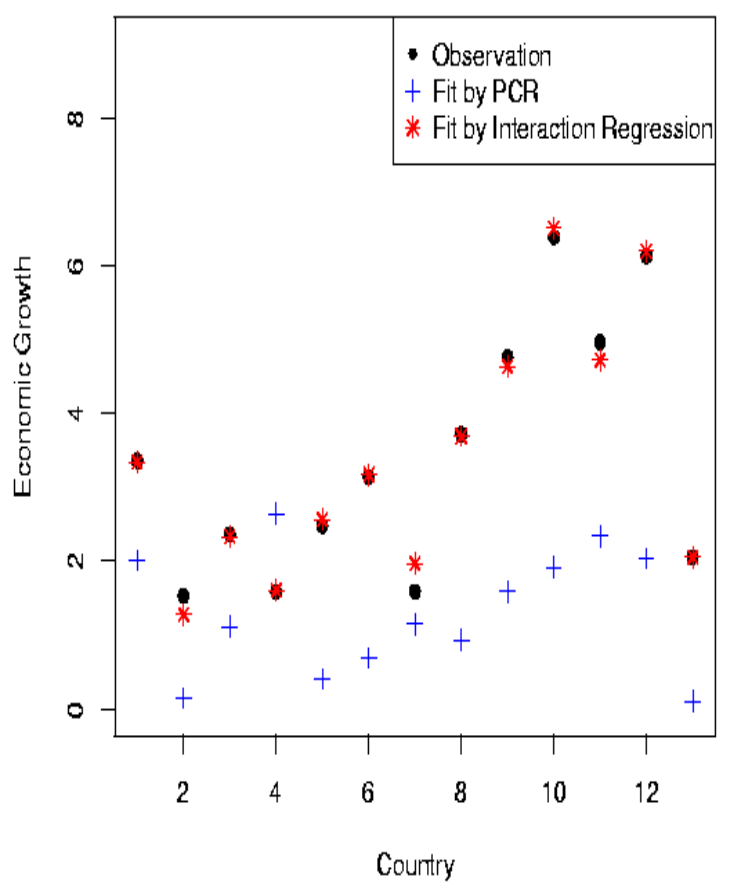

Upper-Middle-Income

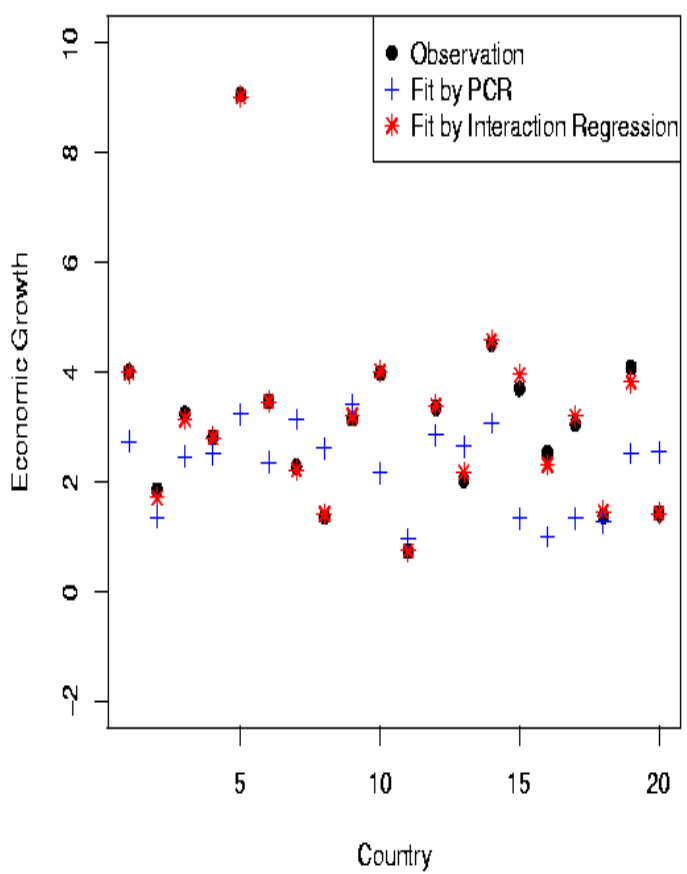

Low-Income

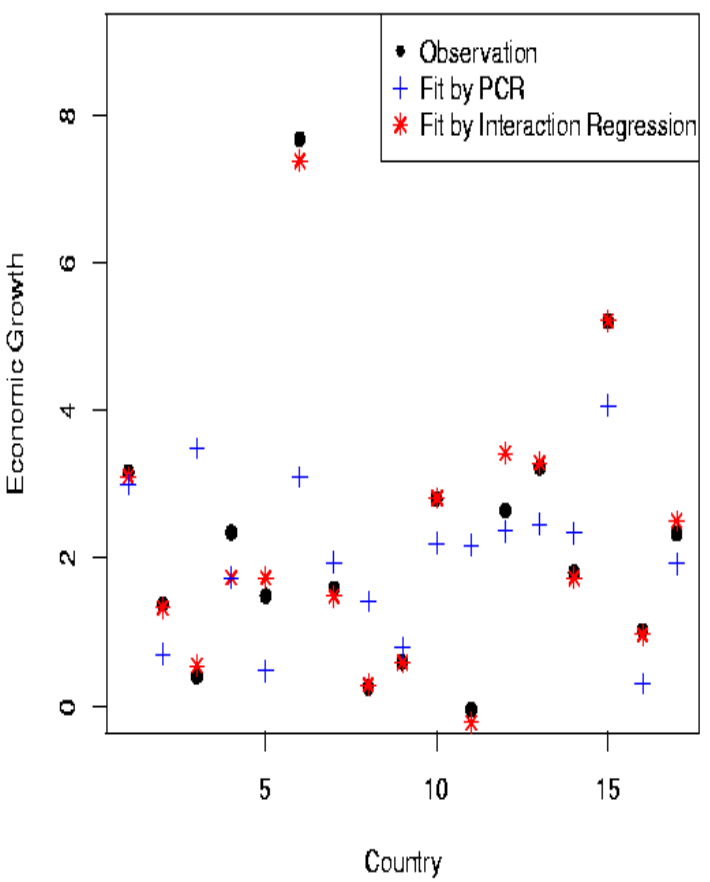

Figure 2. GDP per capita observations and the corresponding fits obtained by the PCR and the Multiple Interaction Regression approaches 

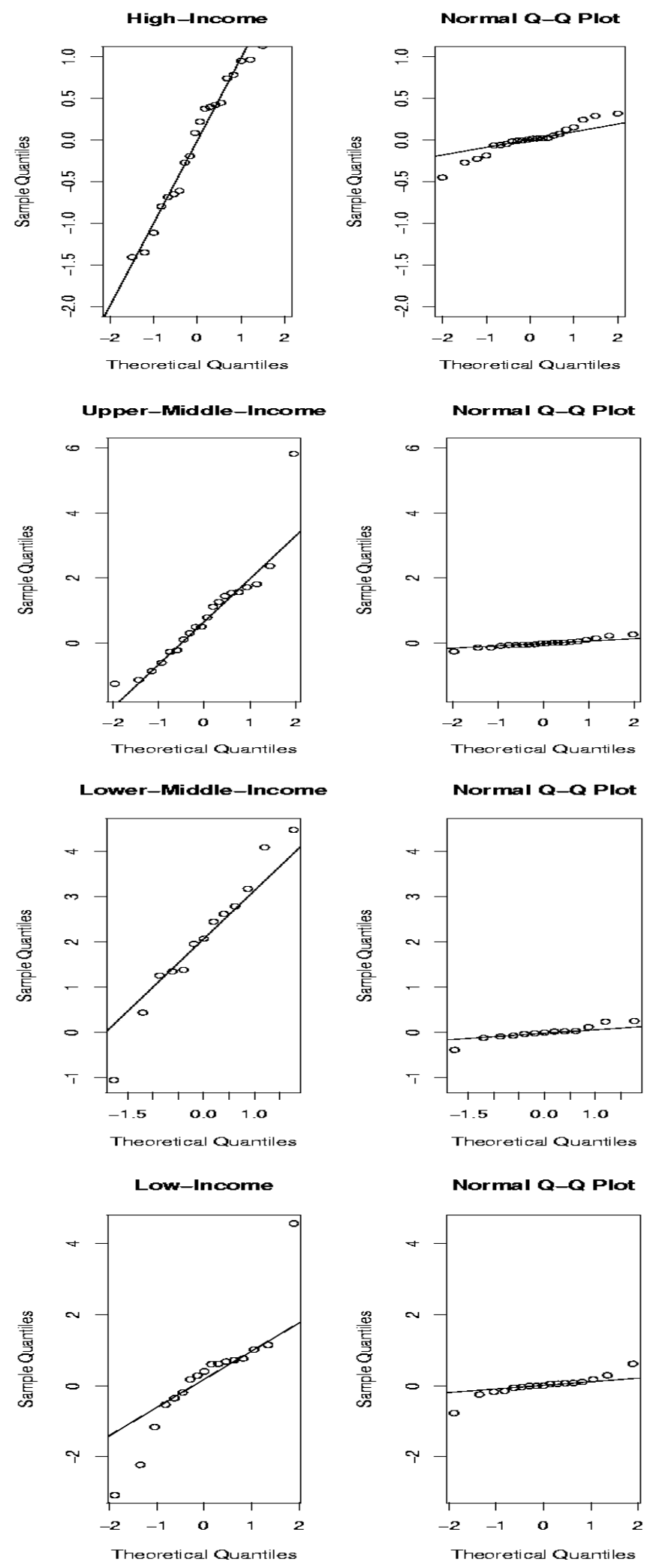

Figure 3. The QQ plots associated with the PCR models (on left) and with the Multiple Interaction models (on right) for income groups 1-4

\section{Interaction Regression Models}

Although the values of the coefficient of determination associated with the PCR linear models are reasonably good, 
they do not reflect highly accurate fits. This may be due to the existing multicollinearity between the original variables, or lack of other affecting factors or both. This problem justifies the need for higher-order interaction terms that may express the underlying physical behavior. Moreover, the inclusion of such terms can eliminate the simultaneity bias, which is important for better statistical results. By using machine-learning, the inter-associations among the independent variables are captured. This step contributed in the formulation of the following four interaction regression models:

Interaction model for High-Income group

$$
\begin{aligned}
& \hat{y}_{c}=-30.9+0.67 w_{c}+2.42 p_{c}+0.00058 g_{c}+29.7 f_{c} \\
& +0.011 w_{c}^{2}+1.33 p_{c}^{2}+\left(1.05 \times 10^{-08}\right) g_{c}^{2}+0.83 w_{c} p_{c} \\
& -0.000029 w_{c} g_{c}-0.97 w_{c} f_{c}-0.00024 p_{c} g_{c}-5.9 p_{c} f_{c} \\
& -0.00062 g_{c} f_{c}-0.000023 w_{c} p_{c} g_{c}+0.16 w_{c} p_{c} f_{c} \\
& +0.000019 w_{c} g_{c} f_{c}+0.000064 p_{c} g_{c} f_{c}
\end{aligned}
$$

where $c=1, \ldots, 22$.

Interaction model for Upper-Middle-Income group

$$
\begin{aligned}
& \hat{y}_{c}=3.33-36.57 p_{c}-0.031 g_{c}-2.67 f_{c}+0.049 w_{c}^{2} \\
& +\left(1.08 \times 10^{-06}\right) g_{c}^{2}-0.43 f_{c}^{2}+2.26 w_{c} p_{c}+0.00099 w_{c} g_{c} \\
& +0.032 p_{c} g_{c}+25.46 p_{c} f_{c}+0.0069 g_{c} f_{c}-0.0017 w_{c} p_{c} g_{c} \\
& -1.23 w_{c} p_{c} f_{c}-0.00025 w_{c} g_{c} f_{c}-0.011 p_{c} g_{c} f_{c} \\
& +0.00053 w_{c} p_{c} g_{c} f_{c}
\end{aligned}
$$

where $c=1, \ldots, 20$.

Interaction model for Lower-Middle-Income group

$$
\begin{aligned}
& \hat{y}_{c}=-35.52+3.09 w_{c}+6.34 p_{c}-0.0056 g_{c}+12.99 f_{c}-0.066 w_{c}^{2}-\left(2.88 \times 10^{-06}\right) g_{c}^{2} \\
& -1.13 f_{c}^{2}-0.57 w_{c} p_{c}+0.00057 w_{c} g_{c}-0.2034 w_{c} f_{c}
\end{aligned}
$$

where $c=1, \ldots, 13$.

Interaction model for Low-Income group

$$
\begin{aligned}
& \hat{y}_{c}=49.41-0.65 w_{c}-0.11 g_{c}-10.44 f_{c}+0.0028 w_{c}^{2} \\
& +\left(3.48 \times 10^{-05}\right) g_{c}^{2}-2.61 p_{c}^{2}+0.013 f_{c}^{2}+0.026 p_{c} g_{c} \\
& +0.29 w_{c} f_{c}+2.25 p_{c} f_{c}+0.0029 g_{c} f_{c}-0.046 w_{c} p_{c} f_{c}
\end{aligned}
$$

where $c=1, \ldots, 17$.

\section{Interaction Regression Analysis Results}

All terms in the developed interaction regression models given in (5-8) are statistically significant at level 0.1 or lower. The introduction of the interaction terms significantly raised the coefficient of determination to $0.9,0.97,0.95$ and 0.92 , respectively. However, the number of the influencing terms, their signs and weights differ from one model to another. Binary interactions are significant in all four models. Joint triple terms including women proportion in parliaments appear significant mostly in the higher-level income models (1) \& (2). Despite that model (3) has the lowest number of terms with insignificant triple or quadruple interactions, a very high percentage of about $95 \%$ of the variation in the growth of this group is explained by the considered factors and their bivariate interactions. Furthermore, the quadruple term, $w_{c} p_{c} g_{c} f_{c}$, turns significant only in the upper-middle economies model (2) where the single term of female parliamentarians, $w_{c}$, appears insignificant. These results reveal the joint influential effects of the considered development 'indicators on nation's economic growth rate. Moreover, the large $R^{2}$ values associated with all income group interaction models indicate superior fits of the adopted dataset, as can be also visualized in Figures 2 and 3 . The remaining small variation in the economic growth of each income category suggests that all other development indicators and the associated interactions, which are not considered in this study, may only explain at most $10 \%$ of a nation's growth variation. More results about this technique are discussed next. 


\section{Discussion}

The main objective of this paper is to assess the economic impact of women's political empowerment, through shares of females in national parliaments, on economic growth. The following four income nation categories of the World Bank are considered: high, upper-middle, lower-middle, and low-income. The sample include some of the top 10 countries by GDP: USA, China, Germany, UK, India, France, Brazil \& Italy. Although this study focuses on the influential impact of women parliamentarians, it does not ignore the effect of other important development indicators such as population growth rates, foreign direct investment, and initial GDP per capita. Panel data for a period of ten years starting 2006 are considered to develop growth models for each economy type.

An initial analysis of the dataset exhibits signs of multicollinearity. To solve this problem and unveil the relationship between growth and women proportion of seats in national parliaments, two regression approaches are implemented. The first approach adopts Principle Components Analysis to fit models on an independent basis. All four developed PCR models explained reasonable percentage of the variations in the GDP per capita and produced 'good' growth estimates, as revealed in Figure 2. The residual diagnostic Q-Q plots in Figure 3 confirm a good normality behavior of errors.

The PCR results provide useful insights into the adopted development factors. Empirical evidence suggests that growth will be enhanced by an increase in the proportion of seats held by women in parliament, where a $10 \%$ increment may rise economic growth of groups $1-4$ by by $0.27 \%, 0.36 \%, 0.22 \%$, and $0.49 \%$, respectively. Findings from implementing this methodology are clearly consistent with the relevant economic theories and studies such as that conducted by Jayasuira and Burkes (2013).

Foreign direct investment is considered as an integral factor of an open international economic system. FDI can play a significant positive role in maintaining a long-run sustainable growth regardless of a nation's level of income. This positive relationship is demonstrated by the corresponding regression coefficient estimates $(0.024,0.04,0.44$, and 0.007$)$ of models 1-4, respectively. These figures indicate that the impact of FDI on growth of the lower-middle economies such as India, Egypt and Morocco can be at least 10 times greater than its impact on the other income groups. This is because such developing countries and emerging economies can benefit more from foreign presence in the domestic economy to increase their competitiveness business environment, enhance enterprise development, and provide employment and training opportunities beside advanced managerial and technological skills to citizens. Moreover, comparing these estimates with the corresponding women parliamentarian terms reveals that both factors may have the same growth stimulating impact on the high and upper-middle economies but FDI can have a stronger impact on the growth of the lower-middle nations. On the contrary, FDI seems to have a small impact on the low-income group, which may be due to the unattractive environment for foreign investments in most of these poor countries. The new results of this study cope with economic theory and previous applied studies, see (Grossman \& Helpman, 1991; Levine \& Renelt. 2003).

As expected, the 2006 initial level of GDP per capita show a small but significant negative effect on the overall growth per capita of all types of economies. However, lower income countries growth rates are more sensitive to initial GDP. This result is consistent with other studies in the literature where, for example, Barro (1991) found growth negatively and robustly related to initial GDP. Levine \& Renelt (2003) and Sala-i-Martine et al. (2004) derived a similar conclusion.

The PCR analysis yielded interesting results regarding the impact of population growth. A higher human growth rate may contribute to either higher or lower economic growth depending on a nation's income. A rapid growth of human population and a high birth rate can have unfavorable effects on high and lower-middle income nations especially countries that are unable to absorb labor surplus. On the contrary, population growth may exert a significant positive impact on upper-middle and low-income countries on the long-run. This is because it is the main source of provision of labor, experts, and business personnel necessary for production activities in such countries (Prihanto, 2017). These results are, for example, in line with the Chinese government move toward ending birth restrictions by 2020, amid the growing concerns over an aging population, a dropping birth rate, and consequently an expected fall in labor force and productivity levels.

Multicollinearity suggests that some interactions between the original variables may have moderate to strong effects on the prediction process. Following the detection of symptoms of data multicollinearity at the initial stage, another regression approach that takes into consideration the joint effects of the adopted predictors on growth is implemented. Fortunately, the innovative method of machine learning technology utilized in this study has identified the significant interactions and links between the proportion of women parliamentarians, development indicators, and GDP/capita. This step produced four new interaction regression models associated with superior statistical results and accurate growth forecasts, as indicated by the fits and Q-Q plots displayed in Figures 2 and 3, respectively.

Despite only four development factors are considered, the new interaction models explain at least $90 \%$ of the variation in the growth rates. This can be interpreted as follows: the proportion of women in national parliaments, for example, may not only provide a measure of women political empowerment but also reflects the combined effect of other growth 
determinants not covered physically in this study. Some of these determinants may include female education, gender equality in different education stages, and female training/skills development, for which parliamentarian females probably benefited from, earlier in their lives, for them to be eligible for such leadership and decision-making positions. The FDI factor, as another example, may reflect the impact of other specific qualitative determinants such as economic openness, economic freedom, global competitiveness and technological progress. Moreover, interactions including proportions of female parliamentarians, FDI or both, for example, may give these factors an additional power that exceeds their impact as independent variables. This is because these joint relationships may represent other more factors such as trained national manpower, which can be achieved, for example, by training male and female citizens in investment projects.

It is impossible to include all factors that have influential effects on economic growth in a single study however; the results derived in this study reveal that the adopted indicators and underlying significant interactions can be adequate. The remaining unexplained small percentages of change in economic growth rates (10\% or less) are probably due to other determinants of GDP/capita, which are either not included nor represented by any terms in the derived models.

Both PCR and interaction regression growth results for all considered nations of the World Bank income groups provide an empirical evidence that reveals the significant role of women in parliaments in stimulating economic growth. Accordingly, the new study affirms that there may be attractive economic incentives for governments to invest women's participation in political life and national parliaments, in particular.

Nations with low proportions of female parliamentarians would have the most to gain from designing policies aimed at engaging more women in the national parliaments and decision-making positions, and from enacting laws and appropriate legislation that can help in achieving the sustainable development goals, of which gender equality represents the fifth UN goal.

\section{References}

Barro, R. (1996). Determination of Economic Growth: A cross-Country Empirical Study. NBER Working Paper, 56(98), 70-71. https://doi.org/10.3386/w5698

Barro, R. J. (1991). Economic growth in a cross section of countries. The quarterly journal of economics, 106(2), 407-443. https://doi.org/10.2307/2937943

Besley, T., Montalvo, J. G., \& Reynal-Querol, M. (2011). Do educated leaders matter?. The Economic Journal, 121(554), F205-227. https://doi.org/10.1111/j.1468-0297.2011.02448.x

Bhoganadam, S., Malini, H., \& Rao, D. (2014). Women's Empowerment and Economic Development. Int. J. multidiscip.res.dev., 4(8), 100-107.

Birdsall, N., Kelley, A. C., Sinding, S. W., \& Sinding, S. (Eds.). (2001). Population matters: demographic change, economic growth, and poverty in the developing world. Oxford University Press. https://doi.org/10.1093/0199244073.001.0001

Blackden, M., Sudharshan, C., \& Stephan, K. et al. (2007). Gender and Growth in Africa: Evidence and Issues. In George Mavrotas and Anthony Shorrocks (Eds), Advancing Development: Core Themems in Global Economics. London: Palgrave Maccmillan.

Carlin, W., \& Soskice, D. (2005). Macroeconomics: imperfections, institutions, and policies. OUP Catalogue.

Dillon, W. R., \& Goldstein, M. (1984). Methods and Applications Multivariate Analysis.

Dollar, D., \& Gatti, R. (1999). Gender inequality, income, and growth: are good times good for women? (Vol. 1). Washington, DC: Development Research Group, The World Bank.

Dollar, D., Fisman, R., \& Gatti, R. (2001). Are women really the "fairer" sex? Corruption and women in government. Journal of Economic Behavior \& Organization, 46(4), 423-429. https://doi.org/10.1016/S0167-2681(01)00169-X

Dormann, C. F., Elith, J., Bacher, S., Buchmann, C., Carl, G., Carré, G., ... \& Münkemüller, T. (2013). Collinearity: a review of methods to deal with it and a simulation study evaluating their performance. Ecography, 36(1), 27-46. https://doi.org/10.1111/j.1600-0587.2012.07348.x

Dritsaki, C., \& Stiakakis, E. (2014). Foreign direct investments, exports, and economic growth in Croatia: A time series analysis. Procedia Economics and Finance, 14, 181-190. https://doi.org/10.1016/S2212-5671(14)00701-1

Elborgh-Woytek, M. K., Newiak, M. M., Kochhar, M. K., Fabrizio, M. S., Kpodar, M. K., Wingender, M. P., ... \& Schwartz, M. G. (2013). Women, work, and the economy: Macroeconomic gains from gender equity. International Monetary Fund. https://doi.org/10.5089/9781475566567.006 
Falki, N. (2009). Impact of Foreign Direct Investment on Economic Growth in Pakistan. Rev. Bus. Res. Pap., 5(5), 110-120.

Grossman, G. M., \& Helpman, E. (1991). Quality ladders in the theory of growth. The review of economic studies, 58(1), 43-61. https://doi.org/10.2307/2298044

Grossman, G., \& Helpman, E. (1991). Innovation and growth in the global economy mit press. Cambridge, MA.

Headey, D. D., \& Hodge, A. (2009). The effect of population growth on economic growth: A meta-regression analysis of the macroeconomic literature. Population and Development Review, 35(2), 221-248. https://doi.org/10.1111/j.1728-4457.2009.00274.X

Hermes, N., \& Lensink, R. (2003). Foreign direct investment, financial development and economic growth. The journal of development studies, 40(1), 142-163. https://doi.org/10.1080/00220380412331293707

Hill, M. A., \& King, E. (1995). Women's education and economic well-being. Feminist Economics, 1(2), 21-46. https://doi.org/10.1080/714042230

Jayasuriya, D. S., \& Burke, P. J. (2013). Female parliamentarians and economic growth: Evidence from a large panel. Applied Economics Letters, 20(3), 304-307. https://doi.org/10.1080/13504851.2012.697113

Kelley, A. C., \& McGreevey, W. P. (1994). Population and development in historical perspective. In R. H. Cassen (Ed.), Population and development: Old Debates, New Conclusions, New Brunswick. NJ and Oxford: Transactions Publishers.

Khorsheed, E. (2019, April). Women Parliamentarians Impact on Economic Growth: A Cross-Country Analysis Evidence. In 2019 8th International Conference on Modeling Simulation and Applied Optimization (ICMSAO) (pp. 1-5). IEEE. https://doi.org/10.1109/ICMSAO.2019.8880280

Klasen, S. (2002). Low schooling for girls, slower growth for all? Cross-country evidence on the effect of gender inequality in education on economic development. The World Bank Economic Review, 16(3), 345-373. https://doi.org/10.1093/wber/lhf004

Klasen, S. (2007). Gender-related indicators of well-being. In Human well-being (pp. 167-192). Palgrave Macmillan, London. https://doi.org/10.1057/9780230625600_7

Klasen, S., \& Lamanna, F. (2009). The impact of gender inequality in education and employment on economic growth: new evidence for a panel of countries. Feminist economics, 15(3), 91-132. https://doi.org/10.1080/13545700902893106

Knowles, S., Lorgelly, P. K., \& Owen, P. D. (2002). Are educational gender gaps a brake on economic development? Some cross-country empirical evidence. Oxford economic papers, 54(1), 118-149. https://doi.org/10.1093/oep/54.1.118

Levine, R., \& Renelt, D. (1992). A sensitivity analysis of cross-country growth regressions. The American economic review, 942-963.

Lucas, R. E. (1988). On the Mechanics of Economic Development. J. Monet. Econ., 22, 3-42. https://doi.org/10.1016/0304-3932(88)90168-7

McConnell, C. R., Brue, S. L., \& Flynn, S. M. (2009). Economics: Principles, problems, and policies. Boston McGraw-Hill/Irwin.

Prihanto, P. H., \& Bhakti, A. (2017). Profile of informal sector workers and factors affecting informal sector employment in Jambi Province. Jurnal Perspektif Pembiayaan dan Pembangunan Daerah, 5(2), 63-70. https://doi.org/10.22437/ppd.v5i2.4417

Sala-i-Martin, X., Doppelhofer, G., Miller, R. (2004). Determinants of Long-Term Growth: A Bayesian Averaging of Classical Estimates (BACE) Approach. Am. Econ. Rev., 94(4), 813-835. https://doi.org/10.1257/0002828042002570

Saqib, N., Masnoon, M., \& Rafique, N. (2013). Impact of foreign direct investment on economic growth of Pakistan. Advances in Management \& Applied Economics, 3(1), 35-45.

Simon, J. L. (1981). The Ultimate Resource (Princeton Univer).

Simon, J. L. (1989). The Economic Consequences of Immigration. Oxford: Basil Blackwell Ltd.

Solow, R. M. (1956). A contribution to the theory of economic growth. The quarterly journal of economics, 70(1), 65-94. https://doi.org/10.2307/1884513 
Stotsky, M. J. G. (2006). Gender budgeting (No. 6-232). International Monetary Fund. https://doi.org/10.5089/9781451864922.001

United Nations. (2005). "Report of the Expert Group Meeting", United Nations Division for the Advancement of Women, Equal participation of women and men in decision-making processes, with particular emphasis on political participation and leadership, Addis-Ababa, Ethiopia, 24-27.

Wheeler, D. C. (2007). Diagnostic tools and a remedial method for collinearity in geographically weighted regression. Environment and Planning A, 39(10), 2464-2481. https://doi.org/10.1068/a38325

Younus, H. S., Sohail, A., \& Azeem, M. (2014). Impact of foreign direct investment on economic growth in Pakistan. World Journal of Financial Economics, 1(1), 2-5. https://doi.org/10.1155/2014/592719

\section{Copyrights}

Copyright for this article is retained by the author(s), with first publication rights granted to the journal.

This is an open-access article distributed under the terms and conditions of the Creative Commons Attribution license (http://creativecommons.org/licenses/by/4.0/). 